\title{
Responding to Racial Discrimination in Indonesia through Multicultural Education
}

\author{
Melisa Prawitasari \\ History Education Department \\ Faculty of Teacher Training and Education \\ Universitas Lambung Mangkurat \\ melisa.prawita@unlam.ac.id
}

\begin{abstract}
Indonesia is an archipelagic country that has a pluralistic society that comes from various tribes, races, religions, beliefs, and has its own culture in each region. In Indonesia's diversity should be a positive value for its citizens. However, it cannot be denied that this diversity can trigger conflict, especially racial discrimination, which is always a hot issue in every conflict that occurs in various regions in Indonesia. To counter conflict due to racial discrimination, there needs to be an understanding of multiculturalism in order to raise awareness by the community about the beauty of the differences. Therefore, the understanding of multiculturalism about awareness of the value of the importance of cultural diversity can be conveyed through educational media that can be planted early which resulting the seeds of racism can be denied early and expected to be lost then to create an Indonesian civil society.
\end{abstract}

Keywords - Racial Discrimination, Multicultural Education

\section{INTRODUCTION}

Indonesia is a country that has various ethnic, racial, ethnic, linguistic, cultural and religious backgrounds, which should be a force to build the nation of Indonesia as every ethnic has its own power in each region. However, behind the diversity is precisely vulnerable to trigger social conflict between communities. Article 5 of the PKS Law (Social Conflict Management Law) states that conflicts can stem from issues related to political, economic and socio-cultural issues, inter-religious conflicts and / or inter- religious, tribal and inter-ethnic, village boundary disputes, city, and /or province, natural resource disputes between communities and / or intercommunities with business actors, as well as unequal distribution of natural resources in the community.

Racial issue, one of the issues that has always been a major issue in Indonesia, resulting in discrimination against certain races. When we look at the news media and social media, the voices tend to be racist still very tight. For example, they tend to see candidates for governors not in terms of achievement but in terms of ethnic, racial and religious backgrounds. And we all realize that such attitudes are not true and not in accordance with the spirit of our nation based on Pancasila and the 1945 Constitution.
In the economic field for example, our society tends to be grouped by race. For example, people tend to think that citizens of Chinese descent are the rich, while citizens of other tribes tend to be considered poor. In spite of these assumptions, our attitude as a nation which tends to let the assumption spread has contributed to the creation of groupings of Indonesian citizens based on labels or assumptions that are not entirely correct and clearly a serious threat to the continuity of the Unitary Republic of Indonesia aspired to the Founding Fathers. Even countless conflicts that occur in each region due to the racism

Therefore, multicultural education is very important to be implemented in order to minimize and prevent the occurrence of conflict, especially the conflict caused by the problem of racial discrimination in various regions of Indonesia. Through a culture-based education, it is expected that students' attitude and mindset will be more opened to understand and appreciate diversity

\section{Discussion}

\section{A. The Problem of Multicultural Education in Indonesia}

Multicultural education that is currently being talked about is not free from the various problems that hinder it. In addition to social problems, multicultural education is also not free from problems in the learning process. Within the framework of learning strategies, cultural-based learning can encourage imaginative, metaphorical, creative thinking, and cultureconscious processes. Nevertheless, the use of local culture (ethnicity) in cultural-based learning is inseparable from the various problems contained in each component of learning, since the initial preparation and implementation.

Some of the early problems of cultural-based learning (multicultural) in the early preparation phase, among others:

1. Teachers are less familiar with their own culture, local culture and learners' culture.

2. Teachers do not master the outline of the structure and ethnic culture of learners, especially in the context of the subjects that will be taught.

3. The low ability of teachers in preparing tools that can stimulate the interest, memory, and re-introduction of 
learners to their respective cultural treasures in the context of their respective cultures as well as in the dimensions of learning experience gained [1].

In fact, the various dimensions of Indonesia's cultural diversity can cause problems in the learning process, especially in classes that ethnic cultures of learners vary greatly.

The problems that appear from multicultural education are two things, namely; First, multicultural education is a process, meaning that the concept of multicultural education that we just started in the world of education in Indonesia requires the process of formulation, reflection, and action on the ground in accordance with the development of fundamental concepts concerning education and human rights. Secondly, multicultural education is a multifaceted one, therefore requesting an interdisciplinary approach, as well as from educational experts and practitioners to further refine and sharpen the concept of multicultural education needed by society[2].

\section{B. Approach and Embodiment of Multicultural Education to Counter Racial DiscriminationIn Indonesia}

In general, multicultural education is a conceptual and practical education that seeks to provide an understanding of racial, ethnic, and cultural diversity within a society. The aim is for people to coexist peacefully between communities of different races, ethnicities, cultures, and religions. In other words, Prof. Dr. AzyumardiAzra, MA defines multicultural education as education for or about cultural diversity in response to demographic and cultural changes in a particular society or even the world as a whole [3].

Dealing with the awareness of the importance of cultural diversity, students must be inculcated that the existing distinction is a necessity or a certainty, but the distinction must be accepted fairly and not to differentiate. That is, the difference needs to be accepted fairly and therefore requiring an attitude of tolerance so that each individual and his community can coexist peacefully.

The Multicultural Education Approach to design education in a community setting that full of inter-group issues such as Indonesia is not easy. This is even more difficult if the existing society still racially discriminatory and racist. Under these circumstances, multicultural education is directed as advocacy to create a tolerant society. As for achieving these objectives, several approaches and approaches in multicultural education are required as follows:

1. No longer equate educational outlook with school view, or multicultural education with formal school programs.

2. Avoid views that equate culture with ethnic groups.

3. Maintaining and extending group solidarity will inhibit socialization into new cultures.

4. Multicultural education enhances cultural competence.

This approach raises awareness of multiculturalism as an individual experience. This awareness implies that multicultural education has the potential to avoid dichotomy and develop a better appreciation through the cultural competencies that exist in the learners. These four approaches must be harmonized with the conditions of Indonesian society. Society is a collection of people or individuals who live and work together in a relatively long time and bound by the unity of the country, culture, and religion.

In realizing multicultural education in Indonesia, according to Kurmaryani (without years) there are at least 4 main things that need to be emphasized, among others:

First, the curriculum model that can be used in multicultural education in Indonesia should reflect the values of Indonesian culture. The curriculum must integrate the learning process of values, knowledge and skills of "life" in a multicultural society, such as: skilled in negotiating, expressing and dealing with differences, conflict resolution, cooperative learning and problem solving which are expected to increase the internalization of Indonesian cultural values in the lives of learners.

Second, teachers also play an important role in realizing multicultural education in Indonesia. A teacher who taught through a multicultural approach should be flexible, because to teach in a multicultural like in Indonesia, consideration of cultural differences is an important issue that should be the teacher's concern. Factors such as: building the paradigm of inclusive and moderate denominations in schools, respecting the diversity of languages, building gender-sensitive attitudes, building a critical understanding of injustice and social status differences, building ethnic discrimination, respecting differences in ability and respecting age differences should be packed in the realm learning and awareness in school, so as to create an understanding to understand and accept all the differences that exist in each individual learners and ultimately learners are expected to have a strong character to always be democratic, pluralist and humanist.

Third, the learning process developed should place learners in the social reality around them. It means, learning process that relies on learners to learn in groups and to compete as a group in a positive competitive situation. In this way, the differences between individuals can be developed as a group power and learners are accosted to living with a variety of cultural, social, economic, intellectual and political aspirations.

Fourth, the evaluation used should include all aspects of the ability and personality of learners in accordance with the objectives and content developed. Performance assessment, portfolio assessment, rubric assessment, observation guidance, interview guidance, rating scale, attitude scale, check-list, questionnaire and others as an assessment tool that can be used to evaluate learning using a multicultural approach.

In addition to school, the community also has an important role in intellectual development and individual personality of learners. Therefore, the community is a place full of alternatives in an effort to enrich the implementation of multicultural-based education process. For that, every member of the community has a moral role and responsibility towards the implementation of multicultural education process. This is 
due to a mutual relationship between society and education. In an effort to empower people in the world of education is an important thing for the advancement of education in the present and in the future.

\section{CONCLUSIONS}

Indonesia whose society consists of various races, ethnic cultures, nations, and religions is important to implement multicultural education. Because it cannot be denied that with this diverse Indonesian society is often the cause of the emergence of various kinds of conflict. In the context of Indonesia, known as a plurality-rich content, the role of multicultural-based education becomes highly strategic in order to manage diversity creatively, so that conflicts that arise as a result of transformation and social reform can be managed intelligently and become part of the nation's enlightenment forward. Multicultural education in Indonesia can only be built through sustainable and integrated efforts. The roles and supports are needed from teachers / faculties, educational institutions, and other education policy makers, especially in the application of curriculum with a multicultural approach.
Teachers and educational institutions (schools) need to understand the concept of multicultural education in a global perspective resulting the values contained in this education can be taught as well as practiced in the presence of learners, so hopefully through the development of this multicultural education the learners will more easily understand the lessons and raising their awareness to always behave humanist, pluralist and democratic

\section{REFERENCES}

[1] E. Samayati, Konsep Pendidikan Multikultural Indonesia, 2014 Retrieved from HYPERLINK "https://plus.google.com/107957266005558152743/posts/K6zF7BDhW1 b" https://plus.google.com/107957266005558152743/posts/K6zF7BDh W1b on 29 September 2017)

[2] Maslikhah, Quo Vadis Pendidikan Multikultur: Rekontruksi Sistem Pendidikan Berbasis Kebangsaan 2007, pp 175

[3] A. Gaus, Kebebasan Beragaman dan Hak-Hak Minoritas di Indonesia, 2008. 